\title{
Studies of the Transferrin Receptor on both Human Reticulocytes and Nucleated Human Cells in Culture
}

\author{
COMPARISON OF FACTORS REGULATING RECEPTOR DENSITY
}

\author{
Janet L. Frazier, Jennifer H. Caskey, Mark Yoffe, and Paul A. Seligman, \\ Division of Hematology/Oncology, Department of Medicine, University of \\ Colorado School of Medicine, Denver, Colorado 80262
}

A B S TRACT The transferrin receptor, present on reticulocytes and nucleated cells in tissue culture, has been measured with both immunoassay techniques and transferrin binding studies. The total cellular immunoreactive receptor is rapidly lost from erythrocytes during the process of reticulocyte maturation (from as many as 400,000 molecules to $<20,000$ molecules/ reticulocyte). This event parallels the loss of cell surface transferrin binding sites and RNA content, and correlates with previous studies that have measured the decline in hemoglobin synthesis.

Nonhemoglobin-producing normal human fibroblasts, which appear to have a much lower iron requirement than reticulocytes, contain similar numbers of immunoreactive receptors per cell $(400,000$ receptor molecules), when in an active state of proliferation. Although receptor density on fibroblasts is directly related to cell proliferation, our studies demonstrate that nonproliferating fibroblasts still retain significant numbers of immunoreactive receptors (150,000 molecules/ cell) and transferrin binding sites. Since additional studies indicate that proliferating cells have increased iron uptake, a simple hypothesis would predict that the parallel increase in transferrin binding sites and total cellular immunoreactive receptor associated with proliferation is related to an increased cellular iron requirement. However, the number of immunoreactive receptor molecules and transferrin binding sites is not changed when cells are grown in iron-deficient media, or in media with added transferrin-iron. This result and the lack of marked differences in receptor number on both hemoglobin-producing and nonhemoglobin-producing cells indicate that other factors besides receptor density play major roles in the regulation of cellular iron uptake, retention, and loss.

Received for publication 30 September 1981 and in revised form 22 December 1981.

\section{INTRODUCTION}

Reticulocytes are anucleate, but contain RNA and synthesize a number of different proteins (1). However, $>90 \%$ of the protein made in reticulocytes is hemoglobin (1) and studies of human cells have estimated that up to $30 \%$ of the hemoglobin found in mature erythrocytes is made at the reticulocyte stage (2). Cells obtain the iron required for hemoglobin synthesis by a process beginning with the binding of the plasma iron transport protein, transferrin, to specific receptors on the cell surface (3). Previously, transferrin binding studies have indicated that transferrin binding sites are found on cells that synthesize hemoglobin, including reticulocytes, but not on mature erythrocytes (3, 4). More recently, binding studies performed on multiple samples of reticulocytes obtained from phenylhydrazine- and actinomycin D-treated rabbits have suggested that even before the reticulocyte completely matures (associated with loss of RNA), transferrin binding sites are almost entirely lost from the cell surface (5). However, whether this decrease represents an alteration or actual loss of receptor is unknown.

Although it has been known for some time that the addition of transferrin to serum-free media provided one of the requirements for cell growth in tissue culture (6), it was not until recently that transferrin binding sites were measured on nonhemoglobin synthesizing cells. However, other than placental cells, which require iron for delivery to the fetus (7-9), the iron requirements of nonhemoglobin synthesizing cells appear to be relatively low (10), and transferrin-bound iron is present in high concentrations in plasma ( 1 $\mu \mathrm{g} / \mathrm{ml})(10)$. There is controversy, therefore, as to why these cells possess relatively large numbers of transferrin binding sites. Some studies suggest that transferrin binding sites are present in measurable quantities only on dedifferentiated or malignant cells but 
not on normal cells (11), and therefore, may represent a marker for transformation. Other experiments (12, 13) indicate that both normal and malignant proliferating cells possess high densities of transferrin binding sites.

We have previously purified the transferrin receptor from human placenta (7) and, using antitransferrin receptor antibody, we have developed a radioimmunoassay for the transferrin receptor. Therefore, using both immunochemical and transferrin binding techniques, we have now measured both immunoreactive receptor protein and transferrin binding sites on reticulocytes and nucleated cells in culture. Using gradient separation of reticulocyte-rich erythrocytes, we demonstrate that the receptor is both functionally lost and immunologically either markedly altered or actually lost from the reticulocyte membrane during the process of reticulocyte maturation. Previous studies have measured transferrin binding sites on human diploid fibroblasts (12-14) and K562 cells (12) in tissue culture, but detailed studies have not directly related the number of binding sites to the state of proliferation of these cells. The studies we have performed on these cells indicate that during proliferation of both fibroblasts and K562 cells immunologic transferrin receptor and transferrin binding sites increase two- to fivefold. The proportionate increase in both total cellular immunoreactive receptor molecules and transferrin binding sites indicates that the increase in transferrin binding by proliferating cells is not due to changes in binding affinity, or availability of receptor, but is associated with an actual increase in receptor molecules.

\section{METHODS}

Human apotransferrin, Sepharose 2B, dextran (clinical grade), and orsinol (RNA assay) were obtained from Sigma Chemical Co., St. Louis, MO. Phytohemagglutinin was purchased from Burroughs-Wellcome Laboratories, Research Triangle Park, NC. Purified OKT-9 monoclonal antibody was a gift from Dr. Robert Mittler (Ortho Laboratories, Raritan, NJ). Previously described methods (7) were used for ${ }^{125}$ I-labeling of transferrin and coupling of human transferrin to Sepharose 2B. Purified human transferrin receptor isolated from placenta with Triton removed (7), and purified OKT-9 monoclonal antibody were labeled with ${ }^{125} \mathrm{I}$ using the method of Bolton and Hunter (15). The iodinated receptor protein had a migration identical to the nonradioactive purified protein on polyacrylamide gels. The method of Bates and Schlambach (16) was used to iron saturate apotransferrin with either ${ }^{59} \mathrm{FeCl}_{3}$ (Amersham Corp., Arlington Heights, IL), or nonradioactive $\mathrm{FeCl}_{3}$. After informed consent, EDTA anticoagulated blood samples containing varying numbers of reticulocytes were obtained from patients and normal subjects. Reticulocyte counts were performed using new methylene blue (17) by determining the percentage in 1,000 cells. The cells used in these studies were obtained from the following laboratories: WI-38 embryonic fibroblasts: Dr. John Lehman, University of Colorado; human skin fibroblasts: Dr. Stuart Gordon, University of Colorado; and K562 human leukemic cells: Dr. Michael Williams, Northwestern University. Minimal essential media with Earle's salts (MEM) ${ }^{1}$ and RPMI 1640 media were obtained from M. A. Bioproducts, Walkersville, MD; fetal calf serum was obtained from Flow Laboratories, Rockville, MD.

All cells were grown in $5 \% \mathrm{CO}_{2}$ atmosphere in media containing $10 \%$ fetal calf serum and either MEM (fibroblasts) or RPMI 1640 (K562 cells). For studies in which fibroblasts were grown in iron-free media, MEM (which contains no measurable iron) was used with $10 \%$ "iron depleted" fetal calf serum. The fetal calf serum was made iron free by dialysis against 50 vol of $10 \mathrm{mM}$ sodium acetate- $\mathrm{NaOH}, \mathrm{pH}$ 5, $10 \mathrm{mM}$ EDTA, and $150 \mathrm{mM} \mathrm{NaCl}$. After dialysis for $24 \mathrm{~h}$, the sera was dialyzed against 20 vol $10 \mathrm{mM} \mathrm{KPO}_{4}$, pH 7.5, $150 \mathrm{mM} \mathrm{NaCl}$ for $12 \mathrm{~h}$, and then against $4 \mathrm{vol}$ of fetal calf serum for another $24 \mathrm{~h}$. Serum iron determinations (Sigma Chemical Co.) showed that iron in the dialyzed serum decreased by $>95 \%$ as compared with predialysis serum.

Antibody to the purified human transferrin receptor was raised in chicken by giving three weekly injections of 100 $\mu \mathrm{g}$ of protein intradermally with all injections mixed $1: 1$ with complete Freund's adjuvant. At the 4th wk blood was removed from a wing vein every $48 \mathrm{~h}$. The chicken antiserum was partially purified by means of ammonium sulfate precipitation and applied to an affinity column containing human transferrin-Sepharose. This latter step was used to remove the small amount of antihuman transferrin antibody in the antisera. The removal of antitransferrin antibody was measured by using a previously described radioimmunoassay for human transferrin (7). Using this technique we found that although $2 \mu \mathrm{l}$ of preaffinity column antisera added to $5 \mathrm{ng}$ of ${ }^{125}$ I-transferrin would specifically precipitate $50 \%$ of the radioactivity, the addition of $20 \mu$ l of postaffinity column antisera specifically precipitated no radioactivity. This latter preparation was used in all of the studies described below in which antihuman transferrin receptor antibody was used. Partially purified control chicken serum used in the experiments was treated in the same manner as described above.

In the experiment measuring antireceptor antibody-mediated inhibition of iron incorporation into reticulocytes, erythrocytes from a patient with sickle cell anemia and a reticulocyte count of $20 \%$ were washed three times (using centrifugation) with $10 \mathrm{mM} \mathrm{KPO}_{4}, \mathrm{pH} 7.5,150 \mathrm{mM} \mathrm{NaCl}$ In the incubation mixture, $100 \mu \mathrm{l}$ of the cell suspension (packed cell volume $50 \%$ ) was added to $300 \mu \mathrm{l}$ of $10 \mathrm{mM}$ $\mathrm{KPO}_{4}, \mathrm{pH} \mathrm{7.5}, 150 \mathrm{mM} \mathrm{NaCl}$, and $1 \mathrm{mg} / \mathrm{ml}$ bovine serum albumin (incubation buffer), $50 \mu \mathrm{l}$ of incubation buffer containing 0-10 $\mu$ l of antireceptor antibody or partially purified control serum, and $50 \mu \mathrm{l}$ (containing $10,000 \mathrm{cpm}$ and $2 \mu \mathrm{g}$ transferrin) of $\left[{ }^{59} \mathrm{Fe}\right]$ transferrin in $10 \mathrm{mM} \mathrm{KPO}_{4}, \mathrm{pH} \mathrm{7.5,150}$ $\mathrm{mM} \mathrm{NaCl}$. Incubation was carried out at $37^{\circ} \mathrm{C}$ for $3 \mathrm{~h} \mathrm{(a}$ time when $70 \%$ of incorporated radioactive iron comigrated with hemoglobin on Sephadex G-150). After the addition of $3 \mathrm{ml}$ of ice-cold incubation buffer, the mixture was centrifuged at $500 \mathrm{~g}$ at $4^{\circ} \mathrm{C}$. The supernatant was then removed and the pellet counted for radioactivity.

Transferrin receptor density on the surface of erythrocytes was qualitatively assayed with a double immunofluorescent antibody technique. In this assay $5 \mu \mathrm{l}$ of a washed (as described above) cell suspension was added to $50 \mu \mathrm{l}$ of incubation buffer containing $2 \mu \mathrm{l}$ of antireceptor antibody. After an incubation at $37^{\circ} \mathrm{C}$ for $30 \mathrm{~min}$, the cells were washed with cold incubation buffer, reconstituted to $100 \mu \mathrm{l}$, and

${ }^{1}$ Abbreviation used in this paper: MEM, Minimal Essential Media. 
reincubated for another $30 \mathrm{~min}$ at $37^{\circ} \mathrm{C}$ with $5 \mu \mathrm{l}$ of a fluorescein-conjugated IgG fraction of rabbit anti-chicken IgG (N. L. Cappel Laboratories Inc., Cochranville, PA). The cells were then washed extensively in incubation buffer and a small amount of new methylene blue reticulocyte stain was added $(2 \mu \mathrm{l} / 200 \mu \mathrm{l}$ cells). The cells were examined with a Zeiss microscope (Carl Zeiss, Inc., New York) using both a phase and fluorescent light source. The percentage of either new methylene blue stained or fluorescent cells was determined after counting 1,000 cells.

Erythrocytes used in all assays were washed three times with $10 \mathrm{mM} \mathrm{KPO}_{4}$, pH 7.5, $150 \mathrm{mM} \mathrm{NaCl}$ at $4^{\circ} \mathrm{C}$ as described above. The final cell pellet was then reconstituted to a packed cell volume of $\sim 50 \%$ and an aliquot was diluted and counted with a hemocytometer. Aliquots of K562 cells were removed from cell suspension cultures and washed in the same manner as erythrocytes. Initially, fibroblasts were removed from monolayers by incubating the cells in EDTA plus $\mathrm{Ca}-$ and Mg-free Earle's salts as described by Hamilton et al. (13). We later found that when adding a small amount of $0.2 \%$ trypsin in $1.0 \mathrm{mM}$ EDTA, cells could be released within 10 $s$ by striking the $\mathrm{T}$-flasks on a counter top, and quickly neutralizing the trypsin with fetal calf serum. This later procedure was faster and resulted in higher cell recovery, but showed no difference in immunoreactive transferrin level or transferrin binding as compared with the former procedure. Before the performance of assays, all cells were assessed for viability with trypan blue and exhibited $>95 \%$ viability. Except for studies measuring radioactive iron uptake and $\left[{ }^{3} \mathrm{H}\right]$ thymidine uptake, in which aliquots of cells were kept in media, cells were pooled and aliquots used for the various studies described below. For the aliquot of cells to be used in the immunoassay, solubilization was carried out by adding Triton X-100 to a final concentration of $0.1 \%$ and sonicating the suspension with a small probe sonicator for $15 \mathrm{~s}$. The mixture was centrifuged at $10,000 \mathrm{~g}$ for $30 \mathrm{~min}$ and the supernatant was assayed. Further solubilization of the remaining pellet or an increase in the Triton X-100 concentration resulted in no further recovery of transferrin receptor.

The radioimmunoassay for human transferrin receptor used a double antibody precipitation technique. Test tubes contained the following: $270 \mu \mathrm{l}$ of the incubation buffer alone or with known amounts of purified human placental transferrin receptor (when calculating a standard curve), 100 $\mu \mathrm{l}$ of incubation buffer containing $0.15 \mu \mathrm{l}$ antireceptor antibody, $50 \mu \mathrm{l}$ of $10 \mathrm{mM} \mathrm{KPO}_{4}, \mathrm{pH} 7.5,150 \mathrm{mM} \mathrm{NaCl}$, and $0.1 \%$ Triton X-100 containing varying amounts of solubilized cells, $50 \mu \mathrm{l}$ of control rabbit serum, and $20 \mu \mathrm{l}(15,000 \mathrm{cpm}$ and $5 \mathrm{ng}$ receptor protein) of ${ }^{125} \mathrm{I}$-receptor. After a $45-\mathrm{min}$ incubation at $37^{\circ} \mathrm{C}, 10 \mu \mathrm{l}$ of purified rabbit anti-chicken IgG (Cappel Laboratories, total protein $15 \mathrm{mg} / \mathrm{ml}$ ) was added. After another $45-\mathrm{min}$ incubation at $37^{\circ} \mathrm{C}$, tubes were immediately put in ice water and $500 \mu \mathrm{l}$ of cold incubation buffer containing $20 \%$ saturated ammonium sulfate (final concentration $10 \%$ ) was added. The tubes were then spun at $1,000 \mathrm{~g}$ for $30 \mathrm{~min}$ at $4^{\circ} \mathrm{C}$. Immediately after centrifugation the supernatant was poured off by inverting the test tubes, the top of each tube was blotted once on filter paper, and the tube, which contained a small visible precipitate, was counted for radioactivity.

For the studies using separation of reticulocytes by dextran gradients $(18,19)$, the cells were reconstituted in Earle's balanced salt solution (without calcium) to a packed cell volume of $\sim 50 \%$. After leukocytes and platelets were removed (20) from the cell suspension, the erythrocytes were applied to dextran gradients in order to separate reticulo- cytes. In these experiments, $750 \mu \mathrm{l}$ of erythrocytes were applied to the top of a discontinuous gradient that contained the following increasing concentrations of dextran (grams/ deciliter) $27,27.8,28.15$, and $28.5 \%$. Gradients were spun for $1 \mathrm{~h}$ at $2,000 \mathrm{~g}$ at $22^{\circ} \mathrm{C}$. Under these conditions various layers of erythrocytes were visualized, removed with a pasteur pipette, washed to remove the dextran, and reconstituted in Earle's balanced salt solution.

Binding studies were performed on cells by incubating varying concentrations $(2-100 \mathrm{ng})$ of ${ }^{125} \mathrm{I}$-transferrin $-{ }^{59} \mathrm{Fe}$ $\left(5,000^{125} \mathrm{I} \mathrm{cpm} / \mathrm{ng}\right.$ transferrin) with $10^{6}-10^{7}$ erythrocytes or $1-3 \times 10^{5}$ nucleated cells in a total incubation mixture of $500 \mu \mathrm{l}$ of Earle's salt solution containing $1 \mathrm{mg} / \mathrm{ml}$ of ovalbumin. Incubations were carried out for $30 \mathrm{~min}$ at $37^{\circ} \mathrm{C}$ (a time when specific binding to receptor was maximal for all cell types). Incubation at $37^{\circ} \mathrm{C}$ was chosen since previous studies measuring binding to fibroblast and K562 cells had been performed at this temperature $(12,13)$. Although the results obtained under these experimental conditions are expressed in this paper (and those cited above) as binding, the data may not reflect pure surface binding since recent studies performed on whole cells incubated with ${ }^{125}$ I-transferrin at $37^{\circ} \mathrm{C}$ indicate that transferrin is internalized (21). After the incubation, the tubes were put in ice water, $2 \mathrm{ml}$ of ice cold Earle's salt solution was added, and the tubes were centrifuged at $500 \mathrm{~g}$ at $4^{\circ} \mathrm{C}$. The supernatant was then aspirated and the pellet counted for radioactivity. Specific binding was determined by subtracting the radioactivity in an identical sample which contained a 1,000-fold excess of nonradioactive transferrin.

Binding studies performed with ${ }^{125}$ I-OKT-9, a monoclonal antibody directed against the putative transferrin receptor (22), were performed in the same manner as ${ }^{125} \mathrm{I}$-transferrin binding, except in place of radioactive transferrin, ${ }^{125} \mathrm{I}-\mathrm{OKT}$ 9 was added $(10,000 \mathrm{cpm} / \mathrm{ng}$ protein). Specific OKT-9 binding was determined by subtracting radioactivity measured in a duplicate sample containing a 100 -fold excess of nonradioactive OKT-9. The specificity of binding of ${ }^{125} \mathrm{I}-\mathrm{OKT}$ 9 to the receptor was also assessed in some experiments by adding an excess of nonradioactive Triton-free purified placental receptor.

Studies measuring ${ }^{59} \mathrm{Fe}$ uptake by cells in tissue culture were performed by adding $\left[{ }^{50} \mathrm{Fe}\right]$ transferrin $(20,000 \mathrm{cpm}$ and $5 \mu \mathrm{g}$ protein) to an aliquot of cells $\left(1-4 \times 10^{6}\right)$ in $5 \mathrm{ml}$ of standard media for $14 \mathrm{~h}$ before the performance of the above assays. Cells were harvested and washed as described above and the cell pellets were counted.

$\left[{ }^{3} \mathrm{H}\right] \mathrm{Thymidine}$ incorporation into DNA was determined (23) by adding $1 \mu \mathrm{Ci}$ of $\left[{ }^{3} \mathrm{H}\right]$ thymidine to $10^{6}$ cells. After a 2.5-h incubation at $37^{\circ} \mathrm{C}$ in $5 \% \mathrm{CO}_{2}$ atmosphere, the cells were harvested, washed, precipitated with $5 \%$ TCA, and the precipitate counted for radioactivity.

\section{RESULTS}

Inhibition of functional transferrin receptor activity mediated by antireceptor antisera. To test the relationship of the antitransferrin receptor antibody to the functional transferrin receptor, we measured ${ }^{59} \mathrm{Fe}$ uptake by reticulocytes incubated in the presence of $\left[{ }^{59} \mathrm{Fe}\right]$ transferrin. As shown in Fig. 1 as little as 0.5 $\mu \mathrm{l}$ of the antitransferrin receptor antibody caused $50 \%$ inhibition of ${ }^{59} \mathrm{Fe}$ uptake by the cells as compared with no inhibition when $10 \mu \mathrm{l}$ of partially purified control chicken serum was added to the incubation mixture. 


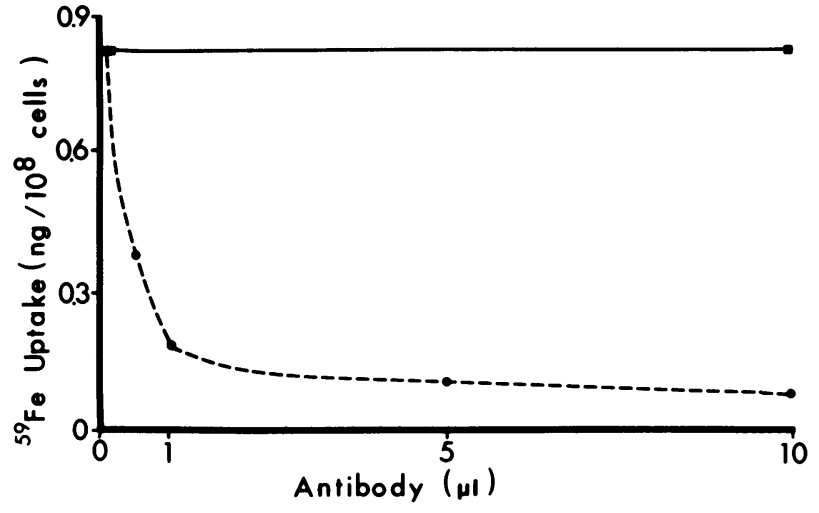

Figure 1 Antireceptor antibody inhibition of $\left[{ }^{59} \mathrm{Fe}\right]-$ transferrin uptake by reticulocytes. Erythrocytes from a patient with sickle cell anemia and a $20 \%$ reticulocyte count were incubated with $\left[{ }^{59} \mathrm{Fe}\right]$ transferrin and partially purified control chicken serum (ם) or antitransferrin receptor antibody (०).

Other studies showed that the antireceptor antibody inhibited the binding of ${ }^{125} \mathrm{I}$-transferrin to reticulocytes (data not shown). Furthermore, in binding studies performed on WI-38 fibroblasts, in an incubation mixture containing $10^{5}$ cells and $20 \mathrm{ng}$ of ${ }^{125} \mathrm{I}$-transferrin, the addition of either $0.1 \mu \mathrm{l}$ of antisera or 1 $\mu$ l of antisera resulted in, respectively, a 44 or $93 \%$ inhibition of specific ${ }^{125}$ I-transferrin binding. The addition of $10 \mu$ l of control sera to the same incubation mixture resulted in no inhibition of binding. These data indicate that the antitransferrin receptor antibody is directed against the functional transferrin receptor found on both reticulocytes and nucleated human cells in culture.

Immunoassay of transferrin receptors on erythrocytes from patients and normal subjects with various reticulocyte counts. Fig. 2 shows the results of studies on erythrocytes using the double antibody immunofluorescent assay. It can be seen that reticulocytes had a rim of membrane-associated fluorescence, whereas mature erythrocytes as well as leukocytes did not. No cell-associated fluorescence was seen when either control chicken serum was added instead of the antireceptor antibody or when $50 \mu \mathrm{g}$ of purified transferrin receptor was added with antireceptor antibody. However, this fluorescence was not quenched when endogenous transferrin bound to receptor was removed by performing several $15-\mathrm{min}$ incubations at $37^{\circ} \mathrm{C}$ in incubation buffer $(19),{ }^{2}$ or with the addition of $>1 \mathrm{mg}$ of human transferrin, indicating that a large portion

\footnotetext{
${ }^{2}$ The removal of $>90 \%$ of the endogenous transferrin was assessed by performing an immunoassay for human transferrin (7).
}
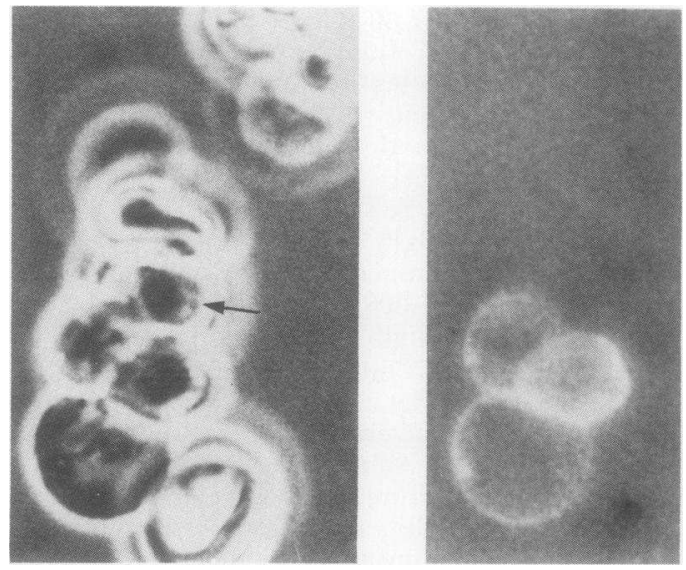

FIGURE 2 Identification of reticulocytes using antireceptor antibody in a double antibody immunofluorescent technique. Using cells from the same patient as in Fig. 1, on the left, seen with a phase contrast light source, is a clump of reticulocytes containing aggregates of RNA, surrounded by mature erythrocytes. The same field on the right using a fluorescent source shows that only reticulocytes are fluorescent whereas mature erythrocytes are not. The arrow shows a reticulocyte containing a relatively small amount of RNA but showing no visible fluorescence.

of the antitransferrin receptor antibody can bind to the transferrin receptor in the absence or presence of bound transferrin. Close inspection of numerous fields showed that the more mature reticulocytes (containing fewer clumps of reticulum) had lighter fluorescence or no observable fluorescence (Fig. 2), suggesting with this qualitative assay that the transferrin receptor was decreased or absent from the surface of the more mature reticulocytes.

Under the conditions of the radioimmunoassay, $30 \%$ of the ${ }^{125} \mathrm{I}$-transferrin receptor precipitated in the absence of unlabeled human transferrin receptor. This value fell significantly and progressively to $5 \%$ as the amount of unlabeled, purified transferrin receptor was increased from 5 to $150 \mathrm{ng}$ (Fig. 3). Since the addition of Triton X-100 by itself resulted in a decrease in the precipitated radioactivity, it was necessary to maintain the same Triton X-100 concentration (final concentration $\mathbf{0 . 0 1 \%}$ ) in all assay tubes. In most immunoassays, control rabbit serum was added to the first incubation mixture to act as a readily available source of nonspecific carrier protein. Since there was a good possibility that the transferrin in the rabbit serum would bind to human receptor (4), some assays were performed without rabbit serum, and slightly less consistent but similar results to those described above were obtained. Under these latter conditions, it could be shown that the value obtained for transferrin receptor protein was not affected by the amount of human transferrin in the in- 
cubation mixture or endogenous transferrin bound to receptor because: $(a)$ the addition of $50 \mu \mathrm{g}$ of human transferrin did not cause inhibition of precipitated radioactivity; and $(b)$ removal of endogenous transferrin by eluting the endogenous transferrin from the cells (19) did not change the calculated value for receptor protein.

Fig. 4 shows the results of the immunoassay performed on solubilized erythrocytes from subjects with various reticulocyte counts. The amount of transferrin receptor increases progressively as the percentage of reticulocytes increases. The increase in receptor with higher reticulocyte counts was not due to an increase in cell size since the patients with high reticulocyte counts had at most a $10 \%$ above normal increase in mean corpuscular volume. Although there was a direct relationship between the reticulocyte counts and the amount of immunoreactive receptor, the relationship was not perfectly linear in that subjects with very high reticulocyte counts $(>8 \%)$ had somewhat higher than expected amounts of receptor, suggesting that these samples contained large proportions of immature reticulocytes.

Conversely, subjects with normal reticulocyte counts had lower than expected levels of receptor. By extrapolation of the results shown in Fig. 4, it can be estimated that a subject with a $5 \%$ reticulocyte count will have $2 \mathrm{ng}$ of receptor $/ 10^{6}$ erythrocytes or, based on a $M_{\mathrm{r}}$ of 180,000 for the receptor, each reticulocyte ( $5 \%$ of total cells) should possess 144,000 receptor molecules. Therefore, a person with a $1 \%$ reticulocyte count would be expected to have the same number of

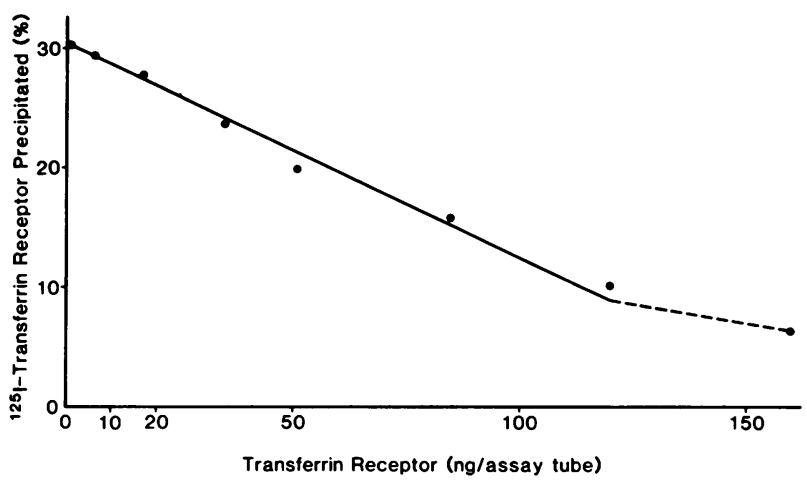

Figure 3 Standard curve obtained using the radioimmunoassay for transferrin receptor. The curve was plotted according to the best fit and each point represents the average of duplicate analyses. Inhibition of precipitated ${ }^{125}$ I-receptor occurs in the presence of various amounts of added nonradioactive-purified transferrin receptor. In the assay shown, the curve is linear with the addition of from 5 to $120 \mathrm{ng}$ of nonradioactive receptor.

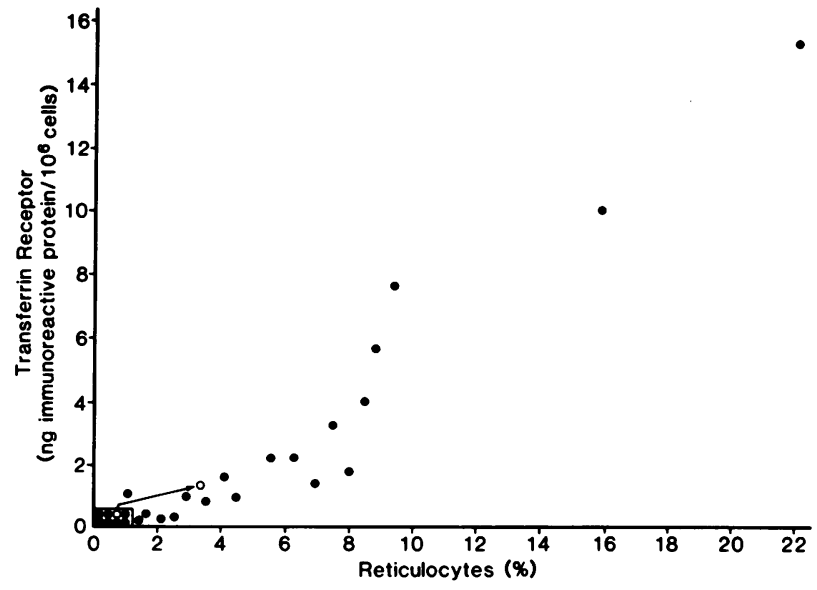

Figure 4 Transferrin receptor on erythrocytes from normal subjects and patients with high reticulocyte counts measured by radioimmunoassay. Points in the rectangle $(\square)$ all have $<0.05 \mathrm{ng}$ receptor $/ 10^{6}$ cells and include a patient with aplastic anemia ( $0.1 \%$ reticulocytes), six normal subjects $(0.7-1.6 \%$ reticulocytes), and a patient with cobalamin deficiency who, as noted by the arrow, increased her reticulocyte count $(3.2 \%)$ and transferrin receptor level $\left(1.8 \mathrm{ng} / 10^{6}\right.$ cells $)$ after treatment with cobalamin.

receptors on each reticulocyte or a total of $0.4 \mathrm{ng}$ of receptor $/ 10^{6}$ erythrocytes. However, six normal subjects $\left(0.7-1.6 \%\right.$ reticulocytes) had $<0.05 \mathrm{ng} / 10^{6}$ cells (Fig. 4), or $<20,000$ receptor molecules/reticulocytes, and a seventh normal subject ( $1.4 \%$ reticulocytes) had $0.1 \mathrm{ng} / 10^{6}$ erythrocytes $(26,000$ molecules/reticulocyte). In contrast, a patient with a hypoplastic bone marrow and a $1.0 \%$ reticulocyte count had 360,000 receptor molecules/reticulocyte and a patient who was hypoxic and had a $1.5 \%$ reticulocyte count had 96,000 receptor molecules/reticulocyte. Also, one of the normal subjects ( $1.6 \%$ reticulocytes) with initially no detectable level of receptor $(<12,000$ receptor molecules/reticulocyte) had a unit of blood removed and $9 \mathrm{~d}$ later increased her reticulocyte count to $2.5 \%$ and number of receptor molecules/reticulocyte to 29,000 (data not shown in Fig. 4). These results suggested that these latter three subjects had more immature reticulocytes in their circulation due to premature release from the bone marrow.

Dextran gradient separation of human reticulocyte-rich erythrocytes. We decided to further study the relationship between the number of receptors on reticulocytes of varying maturity by performing dextran gradient separation of reticulocyte-rich erythrocytes. Since reticulocytes are slightly less dense than mature erythrocytes, previous studies have shown that discontinuous dextran gradients, run under appropriate conditions, result in progressively more buoyant 
layers of cells containing higher percentages of reticulocytes, which also contain more transferrin binding sites per reticulocyte, indicating that these cells can also be separated according to maturity (19). Using gradient separation, increasing percentages of reticulocytes were seen in the more buoyant layers using cells from a patient with autoimmune hemolytic anemia and response to folic acid therapy, who had a $44 \%$ starting reticulocyte count (Table I). The observation that reticulocytes in the more buoyant layers were more immature (larger amounts of RNA) was further supported by the qualitative double antibody immunofluorescent method that identified a higher percentge of reticulocytes in these layers (Table I). Assays for immunoreactive receptor resulted in higher levels of receptor in the more buoyant layers (Table I). Calculations shown in Table I indicate that reticulocytes in the different layers had markedly different numbers of receptor molecules per reticulocyte, a finding that may partly explain why previous binding studies performed on different reticulocyte samples by different authors have reported a similar wide range of calculated number of transferrin binding sites per reticulocyte (4) (range cited in reference 4: estimates from 30-500,000 transferrin binding sites/reticulocyte in studies of both human and rabbit cells).

Table II shows the results of studies done after gradient separation of erythrocytes from a nonhospitalized patient with sickle cell anemia $(<1 \%$ irreversibly sickle cells) and a $28 \%$ reticulocyte count. Assays for RNA using the orsinol reaction (24) (Table II) demonstrated directly that the level of immunoreactive receptor correlated with reticulocyte maturity. When results of assays for ${ }^{125}$ I-transferrin binding were subjected to Scatchard analysis (25) association constants $\left(K_{\mathrm{a}}\right)$ were similar $( \pm 20 \%)$ for all layers and agreed with previous calculations $\left(K_{\mathrm{a}}=1-3 \times 10^{7} / \mathrm{M}\right)(5)$. As expected, however, the calculated amount of transferrin binding sites was higher in the more buoyant layers. Also, the decreases in transferrin binding sites in the less buoyant layers were proportional to decreases in total cellular immunoreactive receptor molecules, supporting the finding that the decrease in binding sites was due to a real loss of receptor molecules rather than changes in binding affinity or a relative shift in receptor molecules away from the cell surface. The values for transferrin binding sites were somewhat lower than the values obtained for immunoreactive receptor, suggesting that there may be an intracellular or intramembrane portion of receptor unavailable for transferrin binding. ${ }^{3}$

In vitro reticulocyte maturation. Studies designed to demonstrate the presence of an intramembrane or intracellular receptor "pool" and/or newly synthesized receptor, unavailable for binding to transferrin, were limited by the occurrence of both reticulocyte "maturation" and receptor degradation, two processes that occurred slowly at $4^{\circ} \mathrm{C}$, but were markedly increased at $37^{\circ} \mathrm{C}$. Thus, cells from a patient with dyserythropoietic anemia, with no demonstrable he-

\footnotetext{
${ }^{3}$ Since each receptor molecule has two subunits of identical molecular weight, the difference between receptor molecules and binding sites appears even more divergent if each receptor molecule has not one, but two transferrin binding sites.
}

TABLE I Assays Performed on Dextran Gradient-separated Erythrocytes from a Patient with Autoimmune Hemolytic Anemia

\begin{tabular}{|c|c|c|c|c|}
\hline & \multicolumn{2}{|c|}{ Reticulocytes } & & \\
\hline & $\begin{array}{l}\text { Supravital } \\
\text { stain }\end{array}$ & $\begin{array}{l}\text { Fluorescent } \\
\text { cells }\end{array}$ & \multicolumn{2}{|c|}{ Immunoreactive receptor } \\
\hline & $\%$ & $\%$ & $n g / 10^{\circ}$ cells & $\begin{array}{l}\text { Receptor molecules } \% \\
\text { reticulocyte }\end{array}$ \\
\hline Start & 44 & 35 & 26.2 & 215,000 \\
\hline Layer $1 \ddagger$ & 99 & 95 & 105.0 & 383,000 \\
\hline Layer 2 & 92 & 80 & 74.4 & 212,000 \\
\hline Layer 3 & 70 & 36 & 32.5 & 168,000 \\
\hline Layer 4 & 28 & 9 & 3.6 & 46,000 \\
\hline
\end{tabular}

- Calculated by relating the amount of immunoreactive receptor (nanograms $/ 10^{6}$ cells) to the $180,000 M_{\mathrm{r}}$ for receptor (6) and calculating the number of molecules on each cell identified as a reticulocyte by supervital staining.

† Top (most buoyant) layer of erythrocytes visualized. 
TABLE II

Assays Performed on Dextran Gradient-separated Erythrocytes from a Patient

with Sickle Cell Anemia

\begin{tabular}{lcccc}
\hline & $\begin{array}{c}\text { Reticulocytes } \\
\text { supravital stain }\end{array}$ & RNA & $\begin{array}{c}\text { Immunoreactive } \\
\text { receptor }\end{array}$ & $\begin{array}{c}\text { Transferrin } \\
\text { binding }\end{array}$ \\
\hline & $\%$ & $n g / 10^{\circ}$ cells & molecules/reticulocyte & sites/reticulocyte \\
Start & 28 & 1.3 & 148,000 & 74,778 \\
Layer 1 & 78 & 5.5 & 259,000 & 124,498 \\
Layer 2 & 47 & 0.8 & 74,000 & 31,491 \\
Layer 3 & 11 & 0.1 & 29,000 & 16,409 \\
\hline
\end{tabular}

- Measured by determining maximal transferrin binding (nanograms) by Scatchard analysis and relating this value to the $80,000 M_{\mathrm{r}}$ for transferrin.

molysis, incubated for $24 \mathrm{~h}$ at $4^{\circ} \mathrm{C}$ showed no change in reticulocyte count (7.4\%) or immunoreactive receptor protein $(107,000$ molecules/reticulocyte), but the same cells incubated at $37^{\circ} \mathrm{C}$ for $24 \mathrm{~h}$ showed decreases in both reticulocyte count and immunoreactive receptor to $2.6 \%$ and 70,000 molecules/reticulocyte, respectively. Immunoreactive receptor was not found in the incubation supernatants, suggesting that if, as Seip (26) had indicated, the in vitro process of reticulocyte maturation corresponds to what happens in vivo, the transferrin receptor is markedly immunologically altered as it is lost from the reticulocyte membrane.

Measurement of transferrin receptor on human mononuclear cells. Normal mononuclear cells separated by Ficoll-Hypaque gradients had no detectable transferrin binding and $<3,000$ receptor molecules/ cell. The same results were obtained for the cells grown in MEM, $10 \%$ fetal calf serum for $2 \mathrm{~d}$. However, an aliquot of the same cells grown for $48 \mathrm{~h}$ in the presence of $0.8 \mu \mathrm{g} / \mathrm{ml}$ of phytohemagglutinin had $55,000 \mathrm{im}$ munoreactive receptor molecules/cell and demonstrable ${ }^{125}$ I-transferrin binding.

These data support the findings of others $(12,27)$, which showed that mitogen-"stimulated" peripheral blood lymphocytes had $>10$ times more transferrin binding sites than "nonactivated" cells. Based on these results, it has been suggested that a high density of transferrin receptor is found only on proliferating cells. However, peripheral blood mononuclear cells may contain an admixture of different types of metabolically inert cells, and the stimulation process may select a small percentage of unstimulated cells that previous studies indicate (27) possess transferrin binding sites. We decided, therefore, to study more homogeneous populations of human cells that could be grown long term in tissue culture.

Measurement of transferrin receptor on human fibroblasts. WI-38 diploid fibroblasts are derived from human embryonic lung cultures, have a finite life-span (remain viable for $\sim \mathbf{4 0}$ passages) and are frequently used as normal controls when comparing different effects associated with transformation (28). Binding of ${ }^{125} \mathrm{I}$-transferrin to both human normal skin and WI-38 human fibroblasts (as described in Methods) was both a specific and saturable process. The calculated association constants $\left(K_{\mathrm{a}}\right)$ obtained for all studies were in the range: $1-2.5 \times 10^{9} \mathrm{M}$. In an incubation mixture containing $10^{5}$ cells and $20 \mathrm{ng}$ of ${ }^{125}$ I-transferrin, the addition of $50 \mathrm{ng}$ of nonradioactive human transferrin iron caused $66 \%$ inhibition of ${ }^{125} \mathrm{I}$-transferrin binding, or about twice the inhibition as the same amount of human apotransferrin, and more significantly, $>100$ times the inhibition as the same amount of transferrin ( $\sim 30 \%$ iron saturated) purified from fetal calf serum. These data indicated that, based on radioactive human transferrin binding, the higher association constant calculated for these cells as opposed to reticulocytes may be due to a lower affinity of the receptor for any endogenously bound fetal calf serum transferrin (see below).

Since we could regulate the amount of iron available to cells grown long term in tissue culture, our first studies performed on fibroblasts related this variable to transferrin receptor density. We found that cells could grow normally for two generations in the presence of the media containing fetal calf serum with iron removed. After about four passages, however, the cells would usually detach and die, suggesting that the cells eventually required iron bound to fetal calf serum transferrin for growth. However, previous studies have suggested (14) that the addition of transferrin-iron to fibroblast media does not appreciably change the number of transferrin binding sites. Table III shows the results of studies designed to assess regulation of the transferrin receptor in regard to the iron content of the media. ${ }^{125} \mathrm{I}$-Transferrin binding studies performed 
TABLE III

Effects of Media Changes on Measurement of Fibroblast Transferrin Receptor

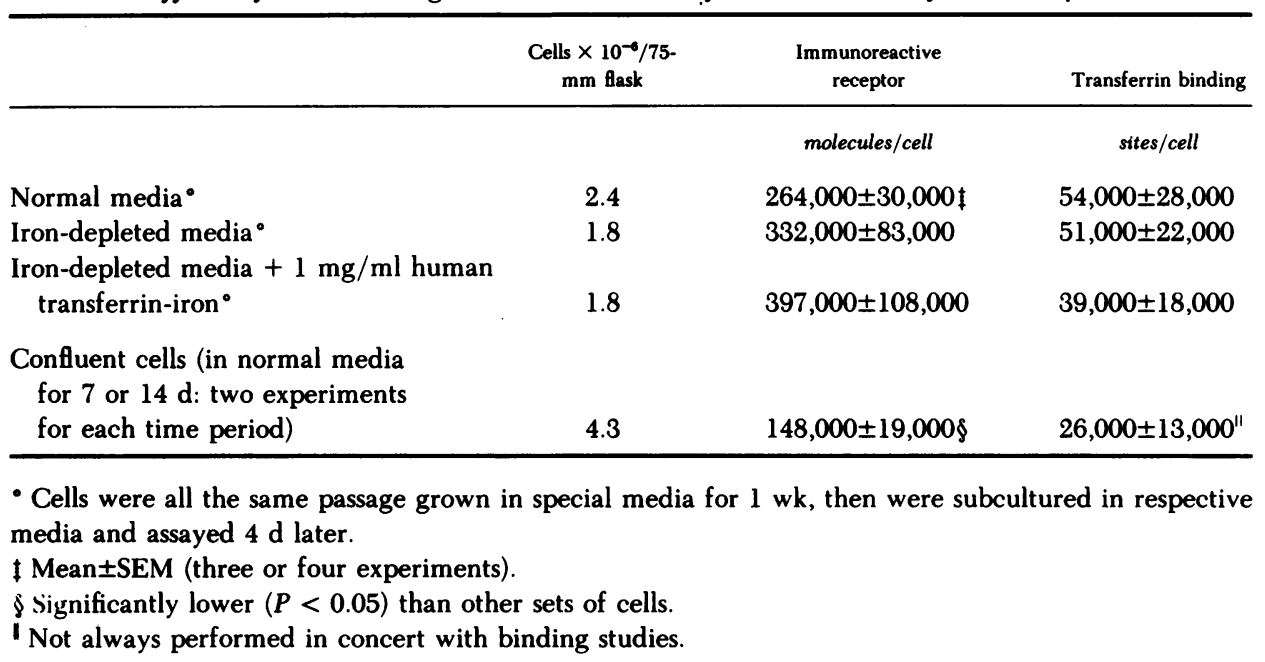

on cells subcultured for two passages in the presence of either normal, iron-depleted, or human transferriniron-supplemented $(1 \mathrm{mg} / \mathrm{ml})$ media resulted in similar numbers of transferrin binding sites. Of interest was the fact that the $K_{\mathrm{a}}$ for the cells grown in human transferrin was always $<50 \%$ of the value obtained for the other sets of cells. These results indicated that a portion of the nonradioactive human transferrin remained associated with the cells during the harvesting process and competed with ${ }^{125}$ I-human transferrin for binding. This competition in binding studies is similar to the competition described when endogenous transferrin remains bound to cells exposed to human serum (8).

The immunoassay resulted in higher calculated values for receptor as compared with binding sites (Table III). This difference was greater than the difference seen with the reticulocyte studies and suggested that an even larger pool of intracellular or intramembrane receptors unavailable for binding may be present in these nucleated cells. As with the binding studies, however, there was no significant difference in the number of immunologic receptor molecules in cells grown in the presence of normal, iron-depleted media, or with added human transferrin-iron. In another experiment, $30 \mu \mathrm{M}$ hemin added to fibroblast media for $4 \mathrm{~d}$ also resulted in similar levels of receptor (data not shown). These results indicated that iron availability had no signficant effect on transferrin receptor density, even while cells were subconfluent and actively growing. When compared with the results of studies performed on confluent cells, however, receptor level of cells in all forms of media was found to be inversely related to the cell density (Table III) which we hypothesized may be related to fibroblasts proliferation. At the same time that these differences were noted, confluent fibroblasts, for as long as $14 \mathrm{~d}$ after subculture (confluent for $>1 \mathrm{wk}$ ), still retained significant amounts of both immunoreactive receptor and transferrin binding sites, with values similar to those obtained for 7-d fibroblasts.

Initial studies designed to measure growth rates of fibroblasts often gave variable results. We found that for consistent growth patterns, it was essential that the cells being compared be of the same passage and subcultured at an appropriate density (slightly $<1 \times 10^{6}$ cells $/ 75-\mathrm{mm}$ T-flask for WI-38 fibroblasts). Table IV shows the results of these studies performed on WI-38 fibroblasts. Cells were subcultured at various days but all cells received fresh media $24 \mathrm{~h}$ before performing assays. As shown in Table IV increased $\left[{ }^{3} \mathrm{H}\right]$ thymidine uptake slightly proceeds the increase in cell growth. Also, immunoreactive transferrin receptor and transferrin binding sites are proportionally increased before the rapid growth spurt. Associated with the increase in transferrin receptor was an increase in intracellular radioactive iron in an aliquot of cells incubated with $\left[{ }^{59} \mathrm{Fe}\right]$ transferrin $14 \mathrm{~h}$ before immunoassays and binding studies were performed. This increase, rather than representing increased iron uptake by cells, may be a result of increased iron retention or decreased iron release (29), but suggests that the increase in transferrin receptor is associated with increased functional activity of the receptor protein and agrees with iron 
TABLE IV

Measurements of Transferrin Receptor on Proliferating Human Fibroblasts

\begin{tabular}{|c|c|c|c|c|c|}
\hline $\begin{array}{c}\text { Time } \\
\text { in } \\
\text { culture }\end{array}$ & $\begin{array}{c}\text { Mean cell number } \\
\times 10^{\circ} / \text { flask }\end{array}$ & $\begin{array}{c}{ }^{3} \text { H]Thymidine } \\
\text { uptake }\end{array}$ & $\begin{array}{l}\text { Immunoreactive } \\
\text { receptor }\end{array}$ & Transferrin binding & Iron uptake ${ }^{\bullet}$ \\
\hline$d$ & & $\mathrm{cpm} / 10^{\circ}$ cells & molecules/cell & sites/cell & $\mathrm{cpm} / 10^{\circ}$ cells \\
\hline 1 & 0.8 & 2,760 & $343,000 \pm 47,000 \ddagger \S$ & $59,000 \pm 23,104^{\prime \prime}$ & 1,310 \\
\hline 3 & 2.1 & 960 & $242,000 \pm 33,000$ & $33,000 \pm 18,000$ & 840 \\
\hline 7 & 4.3 & 154 & $155,000 \pm 22,000$ & $18,000 \pm 4,000$ & 396 \\
\hline
\end{tabular}

- Average of two experiments, all other points are means from three experiments.

$\downarrow$ Mean \pm SEM.

$\S$ Significantly more $(P=<0.05)$ than $7 \mathrm{~d}$ and $P=0.2$ as compared with $3 \mathrm{~d}$.

" $P=0.1$ as compared with $7 \mathrm{~d}$.

incorporation studies performed on mitogen-stimulated lymphocytes (30).

Human skin fibroblasts, from two different adult subjects, gave similar results as WI-38 fibroblasts in that cells measured at $48-72 \mathrm{~h}$ after passage had higher levels of receptor as compared with confluent cells.

Measurement of the transferrin receptor on human leukemic (K562) cells. As opposed to fibroblasts, we found that K562 cells had a consistently predictable growth pattern (Table $\mathrm{V}$ ). Diluted in fresh media to a concentration of $2.5 \times 10^{5} / \mathrm{ml}$, they steadily grew in a "log growth" pattern until reaching a density of $\sim 10^{6}$ cells $3-4 \mathrm{~d}$ after culture. The cells then grew more slowly until day 7 when growth stopped at a concentration approaching $1.5 \times 10^{6}$ cells. At day 7 and for several days afterward, although growth had usually stopped completely, $>90 \%$ of the cells remained viable.
Table $\mathrm{V}$ also shows the measurement of transferrin receptor during growth of K562 cells. As with fibroblasts, total cellular immunoreactive receptor molecules and transferrin binding sites are proportionate and correlate with cell growth. Transferrin binding studies plotted by the method of Scatchard gave similar association constants $\left(K_{\mathrm{a}} 5-8 \times 10^{8} / \mathrm{M}\right)$ in spite of varying levels of receptor number. With K562 cells it was also evident that the peak of transferrin receptor activity slightly preceded the peak of cell growth and coincided with the peak of $\left[{ }^{3} \mathrm{H}\right]$ thymidine uptake. As with fibroblasts, even at a stationary growth phase K562 cells had both measurable transferrin receptor levels as well as transferrin binding. Also, ${ }^{59} \mathrm{Fe}$ taken up by the cells after a 14-h incubation in the presence of human $\left[{ }^{59} \mathrm{Fe}\right]$ transferrin correlated with transferrin receptor levels.

We measured ${ }^{125}$ I-OKT-9 binding to cells (Table V)

TABLE V

Measurement of the Transferrin Receptor on Human Leukemic (K562) Cells ${ }^{\circ}$

\begin{tabular}{|c|c|c|c|c|c|c|}
\hline $\begin{array}{l}\text { Time } \\
\text { in } \\
\text { culture }\end{array}$ & $\begin{array}{c}\text { Mean } \\
\text { cell number }\end{array}$ & $\begin{array}{c}\text { [3H]Thymidine } \\
\text { uptake }\end{array}$ & Immunoreactive receptor & Transferrin binding & $\begin{array}{c}\text { "Specific" } \\
\text { OKT-9 binding }\end{array}$ & ${ }^{\infty} \mathrm{Fe}$ uptake ${ }^{\bullet}$ \\
\hline$d$ & $10^{6} / \mathrm{ml}$ & $\mathrm{cpm} / 10^{\circ}$ cells & molecules/cell & sites/cell & $\mathrm{cpm}^{-3} / 10^{\circ}$ cells & $\mathrm{cpm} / 10^{\circ}$ cells \\
\hline 1 & 0.34 & 8,652 & $1,900,000 \pm 151,000 \ddagger \S$ & $198,000 \pm 32,000^{\prime \prime}$ & 10.9 & \\
\hline 2 & 0.53 & 6,255 & $1,100,000 \pm 69,000$ & $178,000 \pm 42,000$ & 8.6 & 880 \\
\hline 3 & 0.9 & 5,605 & $986,000 \pm 83,000$ & $125,000 \pm 19,000$ & 4.6 & 526 \\
\hline 4 & 1.2 & 3,570 & $560,000 \pm 94,000$ & $80,000 \pm 12,000$ & 4.0 & \\
\hline 7 & 1.4 & 591 & $472,000 \pm 44,000$ & $44,000 \pm 10,000$ & 2.3 & 240 \\
\hline 9 & 1.4 & & $379,000 \pm 72,000$ & $47,000 \pm 5,000$ & 2.3 & \\
\hline
\end{tabular}

- Average from two experiments; all other points are means from three or four experiments.

$\neq$ Mean \pm SEM.

\$ Significantly greater than days $2,3,4,7,9(P<0.05)$

"Significantly greater than days $4,7,9(P<0.05)$. 
in order to use another technique to demonstrate that immunoreactive transferrin receptor increased on the cell surface during proliferation, but remained present on the surface of nondividing cells. OKT-9 is a monoclonal IgG made in mouse that binds to a transferrin binding protein to an immunologic determinant distinct from the transferrin binding site. This binding protein appears to be the transferrin receptor as indicated by molecular weight measurements (21), and by a more recent study that used peptide mapping to demonstrate that the same protein was isolated using either transferrin-Sepharose binding or OKT-9 precipitation (31). In our binding assays, the addition of 3 $\mu \mathrm{g}$ of purified placental receptor completely abolished specific OKT-9 binding, and the addition of $150 \mathrm{ng}$ of receptor protein caused $\sim 50 \%$ inhibition of specific binding. In our studies shown in Table $\mathrm{V}$, the semiqualitative measurement of OKT-9 binding correlated directly with both quantitative total cellular immunoreactive receptor number and transferrin binding sites.

Although there is some controversy (32), several studies indicate that at least certain sublines of K562 cells, which have been cultured from a patient with chronic myelogenous leukemia, can be induced with hemin (33) or sodium-butyrate (34) to initiate hemoglobin synthesis and "differentiate" into erythroid-appearing cells. In studies measuring the effects of added hemin on these cells, we have found that the addition of $30 \mu \mathrm{M}$ hemin to the media was associated with similar growth rates as cells in regular media, and also, that transferrin binding sites, immunoreactive receptor molecules per cell, and iron uptake values were all similar to the values shown in Table $\mathrm{V}$. These data agree with a recent report (35) that indicated that K562 cells, which avidly take up hemin from the media, continued to take up equivalent amounts of iron with or without added hemin, whereas rabbit reticulocytes decreased iron uptake when hemin was added.

\section{DISCUSSION}

Our studies have utilized a radioimmunoassay as a new tool in the measurement of transferrin receptor on reticulocytes and nonhemoglobin-synthesizing cells in tissue culture. Our results agree with a recent independent study performed by Enns et al. (36), which used a different radioimmunoassay to measure transferrin receptor on a placental cell line in tissue culture and determine an increased amount of receptor on a reticulocyte-rich erythrocyte sample as compared with a normal erythrocyte sample. We have also performed detailed studies measuring both immunoreactive receptor levels and transferrin binding sites on a large number of samples containing reticulocytes of varying maturity and serial samples of proliferating and nonproliferating normal and malignant cells in tissues culture.

Although it has been suggested for some time (3) that the functional transferrin receptor was lost when reticulocytes matured into normal erythrocytes, little has been known concerning the rate of receptor loss and the fate of the receptor protein during the process of maturation. Recently, measurements of reticulocyte-rich samples taken from rabbits (5) and another study using gradient separation of rabbit reticulocytes (19) have both indicated that samples containing morphologically mature reticulocytes had fewer transferrin binding sites and less iron uptake as compared with immature reticulocytes. Using discontinuous dextran gradient separation of human reticulocyte-rich blood samples, we have additionally shown that not only are functional transferrin binding sites markedly increased on the more immature reticulocytes, but there is also a proportionate increase in total cellular immunoreactive receptor indicating that increased transferrin binding sites and iron uptake is due to an actual increase in receptor molecules. Conversely, the more mature reticulocytes in patients with high reticulocytes counts or the bulk of the reticulocytes found in normal blood have low or undetectable levels of both functional transferrin binding sites and immunoreactive receptor, indicating that the receptor protein is either markedly altered immunologically or entirely lost from the reticulocyte membrane to a large extent before the reticulocyte completely matures. This loss of receptor correlates with studies performed on human reticulocytes that demonstrated that only half of the reticulocytes, which in humans represented immature bone marrow reticulocytes, synthesized $>90 \%$ of the hemoglobin produced (2).

We hypothesized that utilization of the above findings might improve the clinical application of the peripheral blood reticulocyte count, which is essential in the evaluation of patients with anemia as an index of the rate of erythropoiesis. Several studies have indicated that during times of increased erythrocyte loss, a reticulocytosis is not only due to an increase in erythropoiesis, but to a variable degree also results from the stimulus for premature release of immature "stress" or "shift" reticulocytes from the bone marrow $(2,37)$. Therefore, in concert with standard assays for reticulocytes an assay using immunoreactive receptor measurements to determine the proportion of immature reticulocytes would add to the utility of the reticulocyte count by providing a better index of the rate of erythropoiesis. Recently, using the fluorescent double antibody technique, we developed, in collaboration 
with others, an automated fluorescent detection system that selectively recognized immature reticulocytes in studies performed on rats. ${ }^{4}$

Several recent studies have shown the existence of transferrin binding sites on nonhemoglobin-synthesizing malignant and transformed cells in both tissue culture $(12,13,38,39)$ and in vivo (11). It has been suggested $(11,39)$, therefore, that high densities of binding sites are associated only with malignancy or transformation. Other studies, however, performed mainly on mitogen-"stimulated" peripheral blood lymphocytes indicate that transferrin binding sites are markedly increased on all cells during the process of proliferation $(12,13,22,27,40-43)$, thus supporting suggestions that more iron is required by dividing cells $(44,45)$. Our studies have not only shown that both normal fibroblasts and leukemic cells in culture have increased density of immunoreactive transferrin receptor molecules slightly proceeding and during the most active state of proliferation, but additionally demonstrate, as opposed to maturing reticulocytes, that "resting," nonproliferating cells still retain about one-fifth to one-third of the immunoreactive receptor molecules. These data may indicate that the transferrin receptor is being actively synthesized, but at a reduced rate, when cells are not proliferating. Alternatively, as has been suggested (41), receptor synthesis may cease completely when cells are not proliferating and the persistence of receptors found on nonproliferating fibroblasts and leukemic cells may be entirely due to a prolonged receptor half-life.

Our studies indicate that each nondividing fibroblast retains $\sim 150,000$ total immunoreactive receptor molecules and 25,000 transferrin binding sites. The latter value compares with 30,000 low density lipoprotein binding sites/cell (46) and 5,000 insulin binding sites/cell (47) previously measured on fibroblasts.

Our results show that the increase in transferrin binding sites associated with proliferation is proportionate to the increase in total cellular immunoreactive receptor molecules, indicating that increased transferrin binding on proliferating cells is not due to changes in receptor binding affinity, or to changes in receptor availability caused by a shift of intracellular receptor to the cell surface, but rather is associated with an actual increase in receptor molecules. The results of the two assays indicate that there are fewer binding sites than immunoreactive receptor molecules,

\footnotetext{
${ }^{4}$ Seligman, P. A., R. H. Allen, S. J. Kirchanski, and P. M. Natale. Automated analysis of reticulocytes using fluorescent staining with both acridine orange and an immunofluorescent technique. Submitted for publication.
}

which suggests that there may be a large pool of intracellular or intramembrane receptor unavailable for binding. Conclusions based on the comparison of the quantitative results of the two assays may be premature, however, particularly since binding studies may vary when either different amounts of endogenous transferrin are present $(7,8)$ or if a variation in the rate of cellular internalization of transferrin occurs (21).

Our studies indicate that the amount of iron available to cells has no demonstrable effect on receptor density suggesting that other factors besides receptor density are important in the regulation of iron uptake, retention, and loss by cells. For example, since free iron is toxic to cells an important regulator or intracellular iron concentration appears to be both the level of cellular ferritin and different factors responsible for the release of iron from ferritin $(48,49)$. Thus in our experiments, although changes in the iron content of the media was associated with no change in transferrin receptor density, we found that cell-associated immunoreactive ferritin increased two- to threefold in cells grown in media containing human transferriniron or hemin, and decreased three- to sevenfold in cells grown in iron-depleted media.

Although nonhemoglobin-synthesizing cells may contain substantial amounts of iron bound to ferritin, measurements of total body iron indicate that these cells require very small amounts of iron at any one point in time for incorporation into iron-containing enzymes (10). Therefore, the presence of a high density of transferrin receptors on iron-supplemented cells, and the increase in receptor density associated with proliferation appear to be more complicated processes than simply a reflection of what is presently known about the iron requirements of the cell. Transferrin receptor density may be high, however, in order to supply transferrin-bound iron to a kinetically active iron pool which cannot be supplied by ferritin iron and is a necessary requirement for unknown cellular processes including those associated with proliferation. Alternatively, high receptor density may reflect a function for transferrin other than iron transport, including delivery of other divalent cations such as zinc (50).

Whatever the mechanism for receptor regulation, however, further elucidation of the physiologic role played by changes in transferrin receptor density should include studies performed in parallel that measure iron uptake, retention, and release by cells.

\section{ACKNOWLEDGMENTS}

This work was supported by grant AM27039 awarded by the National Institutes of Arthritis, Metabolic Diseases and 
Digestive Disease, Department of Health, Education, and Welfare, and a research grant awarded by the Chapman Research Fund.

\section{REFERENCES}

1. Lodish, H. F., B. Small, and H. Chang. 1975. Maturation of rabbit reticulocytes: degradation of specific reticulocyte proteins. Dev. Biol. 47: 59-67.

2. Papayannopoulou, T., and C. A. Finch. 1975. Radioiron measurements of red cell maturation. Blood Cells. 1 535-546.

3. Jandl, J. H., and J. H. Katz. 1963. The plasma to cell cycle of transferrin. J. Clin. Invest. 42: 314-326.

4. Aisen, P., and E. B. Brown. 1975. Structure and function of transferrin. Prog. Hematol. 9: 25-56.

5. Van Bockxmeer, F. M., and E. H. Morgan. 1979. Transferrin receptors during rabbit reticulocyte maturation. Biochim. Biophys. Acta. 584: 76-83.

6. Tormey, D. C., and G. C. Meuller. 1972. Biologic effects of transferrin on human lymphocytes in vitro. Exp. Cell Res. 74: 220-226.

7. Seligman, P. A., R. B. Schleicher, and R. H. Allen. 1979. Isolation and characterization of the transferrin receptor from human placenta. J. Biol. Chem. 254: 9943-9946.

8. Wada, H. G., P. E. Hass, and H. H. Sussman. 1979. Transferrin receptor on human placental brush border membranes. J. Biol. Chem. 254: 12629-12635.

9. Loh, T., D. A. Higuchi, F. M. Van Bochxmeer, C. H. Smith, and E. B. Brown. 1980. Transferrin receptors on the human placental microvillous membrane. J. Clin. Invest. 65: 1182-1191.

10. Fairbanks, V. L., and E. Beutler. 1977. Iron metabolism. In Hematology. W. J. Williams, editor. McGraw-Hill, New York. 168.

11. Faulk, W. P., B. L. Hsi, and P. J. Stevens. 1980. Transferrin and transferrin receptors in carcinoma of the breast. Lancet. II: 390-392.

12. Larrick, J. W., and P. Creswell. 1979. Modulation of cell surface iron transferrin receptors by cellular density and state of activation. J. Supramol. Struct. 11: 579-586.

13. Hamilton, T. A., H. G. Wada, and H. H. Sussman. 1979. Identification of transferrin receptors on the surface of human cultured cells. Proc. Natl. Acad. Sci. U. S. A. 76: 6406-6410.

14. Ward, J. H., J. P. Kushner, and J. Kaplan. 1981. Fibroblast transferrin receptors in normal human subjects and in patients with hemochromatosis. Clin. Res. 29: 352A.

15. Bolton, A. E., and W. M. Hunter. 1973. The labelling of proteins to high specific radioactivities by conjugation to a ${ }^{125}$ I-containing acylating agent. Biochem. J. 133: 529-539.

16. Bates, G. W., and M. R. Schlambach. 1973. The reaction of ferric salts with transferrin. J. Biol. Chem. 248: 32283232.

17. Atwater, J., and A. J. Erslev. 1977. Reticulocyte staining. In Hematology. W. J. Williams, editor. McGraw-Hill, Inc., New York. 1590.

18. Schulman, H. M. 1967. The fractionation of rabbit reticulocyte. Biochim. Biophys. Acta. 148: 251-255.

19. Witt, D. P., and R. C. Woodworth. 1978. Identification of the transferrin receptor of the rabbit reticulocytes. Biochemistry. 17: 3913-3916.

20. Beutler, E., C. West, and K. G. Blume. 1976. The removal of leukocytes and platelets from whole blood. $J$. Lab. Clin. Med. 88: 328-334.
21. Karin, M., and B. Mintz. 1981. Receptor-mediated endocytosis of transferrin in developmental totipotent mouse teratocarcinoma stem cells. J. Biol. Chem. 256: 3245-3252.

22. Sutherland, R., D. Delia, C. Schneider, R. Newman, J. Kemhead, and M. Greaves. 1981. Ubiquitous cell-surface glycoprotein on tumor cells is proliferation associated receptor for transferrin. Proc. Natl. Acad. Sci. U. S. A. 78: 4515-4519.

23. Bradley, L. M. 1980. Mitogen-induced responses. In Selected Methods in Cellular Immunology. B. Mishell and S. M. Shiigi, editors. W. H. Freeman and Co., San Francisco. 156-158.

24. Thach, R. E., and M. R. Newburger. 1972. Research Techniques in Biochemistry and Molecular Biology. W. A. Benjamin, Inc., New York. 36-38.

25. Scatchard, G. 1949. The attractions of proteins for small molecules and ions. Ann. N. Y. Acad. Sci. 51: 660-672.

26. Seip, M. 1953. Reticulocyte studies. Acta Med. Scand. 146(Suppl. 282): 1-164.

27. Galbraith, R. M., P. Werner, P. Arnand, and G. M. P. Galbraith. 1980. Transferrin binding to peripheral blood lymphocytes activated by phytohemagglutinin involves a specific receptor: ligand interaction. J. Clin. Invest. 66: 1135-1143.

28. Lehman, J. M., I. B. Klein, and L. S. Craton, 1979. Flow cytometry analysis of early DNA changes in human and monkey cells following infection with Simian virus 40 . J. Supramol. Struct. 11: 579-586.

29. Baker, E., F. R. Vicary, and E. R. Huebens. 1981. Iron release from isolated hepatocytes. $\mathrm{Br}$. J. Haematol. 47: 493-504.

30. Brock, J. H., and C. Roukin. 1981. Transferrin binding and iron uptake by mouse lymph node cells during transformation in response to concanavalin A. Immunology. 43: $393-398$

31. Goding, J. W., and G. F. Burns. 1981. Monoclonal antibody OKT -9 recognizes the receptor for transferrin on human acute lymphocytic leukemia cells. J. Immunol. 127: 1256-1258.

32. Lozzio, B. B., and C. B. Lozzio. 1979. Absence of erythrocytic components in the original $\mathrm{K} 562$ cell line. Int. J. Cancer. 24: 513.

33. Rutherford, T. R., J. B. Clegg, and L. Weatherall. 1979. K562 human leukemic cells synthesize embryonic hemoglobin in response to hemin. Nature (Lond.). 280: 164-165.

34. Anderson, L. C., M. Jokinen, and C. G. Gahenberg. 1979. Induction of erythroid differentiation in the human leukemia cell line K562. Nature (Lond.). 278: 364-365.

35. Schulman, H. M., A. Wilcznska, and P. Ponka. 1981. Transferrin and iron uptake by human lymphoblastoid and $\mathrm{K} 562$ cells. Biochem. Biophys. Res. Commun. 100: 1523-1530.

36. Enns, C. A., J. E. Shindelman, S. E. Tonik, and H. H. Sussman. 1981. Radioimmunochemical measurement of the transferrin receptor in human trophoblast and reticulocyte membranes with a specific anti-receptor antibody. Proc. Natl. Acad. Sci. U. S. A. 178: 4222-4225.

37. Brecker, G., J. E. Haley, M. Prenant, and M. Bessis. 1975. Macronormoblasts, macroreticulocytes, and macrocytes. Blood Cells. 1: 547-553.

38. Hemmaplardh, D., and E. H. Morgan. 1974. Transferrin and iron uptake by human cells in culture. Exp. Cell Res. 87: 207-215.

39. Galbraith, G. M. P., R. M. Galbraith, and W. P. Faulk. 
1980. Transferrin binding by human lymphoblastoid cell lines and other transformed cells. Cell. Immunol. 49: 215-222.

40. Trowbridge, I. S., and M. B. Omary. 1981. Human cell surface glycoprotein related to cell proliferation is the receptor for transferrin. Proc. Natl. Acad. Sci. U. S. A. 78: 3039-3043.

41. Omary, M. B., I. S. Trobridge, and J. Minowada. 1980. Human cell-surface glycoprotein with unusual properties. Nature (Lond.). 286: 888-891.

42. Judd, W., C. A. Poodry, and J. L. Strominger. 1980. Novel surface antigen expressed on dividing cells but absent from nondividing cells. J. Exp. Med. 152: 14301435.

43. Haynes, B. F., M. Hemler, T. Cotner, D. L. Mann, G. S. Eisenborth, J. L. Strominger, and A. S. Fauci. 1981. Characterization of a monoclonal antibody (SE9) that defines a human cell surface antigen of cell activation. J. Immunol. 127: 347-351.

44. Hoffbrand, A. V., K. Ganeshagurer, J. W. L. Hooton, and M. H. N. Tattersall. 1971. Effect of iron deficiency and desferrioxamine on DNA synthesis in human cells. Br. J. Haematol. 33: 517-526.

45. Dallman, P. R., E. Beutler, and C. A. Finch. 1978. Effects of iron deficiency exclusive of anaemia. Br. J. Haematol. 40: 179-184.

46. Brown, M. S., and J. L. Goldstein. 1979. Receptor-mediated endocytosis: insights from the lipoprotein receptor system. Proc. Natl. Acad. Sci. U. S. A. 76: 3330-3337.

47. Mott, D. M., B. V. Howard, and P. H. Bennett. 1979. Stoichiometric binding and regulation of insulin receptors on human diploid fibroblasts using physiologic insulin levels. J. Biol. Chem. 254: 8762-8767.

48. Munro, H. N., and M. C. Linder. 1978. Ferritin: biosynthesis and role in iron metabolism. Physiol. Rev. 58: 317-396.

49. Aisen, P., and I. Listowsky. 1980. Iron transport and storage proteins. Annu. Rev. Biochem. 49: 3-47.

50. Phillips, J. L. 1976. Specific binding of zinc transferrin to human lymphocytes. Biochem. Biophys. Res. Commun. 72: 634-639. 